\title{
On the inventory of sociological violence research
}

\section{A brief introduction}

\author{
Andreas Braun • Thomas Kron
}

(C) The Author(s) 2020

Sociological violence research has changed within some decades. Besides former debates on the use of qualitative instead of quantitative research paradigms (e.g., Trutz von Trotha), the explicit focus on physical violence and the suffering of the victims (e.g., Wolfgang Sofsky), or the plea for an explicit focus on violent situations as the key in explaining violent actions (e.g., Randall Collins), a broad field of research has established. Dealing with several and different sociological theories, sociological violence research is now surely no longer describable as being on the margin of general sociological research interests. Nevertheless, the sociology of violence has to face many challenges, especially regarding their further theoretical development, their potential use for broader sociological theories or the question of how to deal with new possibilities of data. The latter mainly challenged by technological progress and the internet-for instance, big data, video data uploaded by perpetrators, hate speech on social media, etc.

Against this backdrop, and regarding the amount of several recent publications, we-the editors - thought it is time to focus on the different developments within the sociology of violence by taking an inventory. Kindly the Österreichische Gesellschaft für Soziologie shared our opinion so that we can present the current special issue.

The aim of this special issue on the inventory of sociological violence research is to shed some light on current discourses. Thereby we can present a mixture of articles, taking not only both theoretical and empirical questions into account, but

\footnotetext{
A. Braun $(\bowtie)$

Fakultät für Soziologie, Universität Bielefeld, Universitätsstraße 25, 33615 Bielefeld, Germany

E-Mail: andreas.braun@uni-bielefeld.de

T. Kron

Institut für Soziologie, Lehrstuhl für Soziologie, RWTH Aachen University,

Eilfschornsteinstr. 7, 52062 Aachen, Germany

E-Mail: tkron@soziologie.rwth-aachen.de
} 
also aspects of preventing violence-a part often disregarded when talking about and questioning the use of sociological violence research. Randall Collins, for example, emphasizes the relevance of his situationalist research, especially as a scientific contribution to the prevention of violence. On the other hand, although truly not intended, this special issue focuses on and discusses the use of situational approaches - an aspect that is of current relevance regarding recent discussions on how one could adequately explain violence. Here we follow critics of the use of such a situational perspective who-too early?-have proclaimed the farewell of this approach in various places. Especially in the german-speaking context, situational approaches are recently challenged by different perspectives-for instance, processual approaches or reflexive constructions of violence, depending on changing social rules of procedures. Here we start with Andreas Braun, who introduces this special issue with a short stocktaking review of these (more or less) contrary perspectives that currently characterize the sociological discourse and can be submitted under the keywords situation, process as well as reflexivity and varying orders.

Against this backdrop, and pointing to the debate of either explaining violence by focusing on situations or contexts, Tabea Koepp and Chris Schattka show that such a contrast reading is unnecessary-rather a curious debate that overlooks possibilities of theoretical integration. They propose a context-sensitive micro-sociology of violence which integrates trans-situational elements into the explanation based on detailed reconstructions. They demonstrate the potentials of this integrative perspective with two case studies on the Srebrenica Massacre of 1995 and the escalation of the Welcome to Hell Demonstration in Hamburg 2017. The challenge is to develop an integrative perspective on violent situations that takes into account the actions, expectations, and evaluations of the involved actors and to link the situational dynamics with trans-situational references consistently.

With such a perspective of integration and by taking "modern civilized" societies into account, Johannes Ebner and Marion Stopfinger focus on the use of combining situational and processual perspectives following the approaches of Randall Collins and Norbert Elias in the context of sexual violence in war. They show that both micro- and figuration-sociological research on violence would benefit from looking at their axioms from the perspective of the other approach and taking their objections seriously. Furthermore, both theories contribute to eliminating deficiencies in the analysis of sexual violence in war: They counteract the normativity of the media, political, and scientific debate and contribute to a more precise and objective definition of terms.

The so-far theoretical as well as empirical articles, discussing violence within the broad field of massacres, demonstrations, and sexual violence in war, are supplemented by a further perspective on a hitherto minor sociologically observed violent aspect-the case of medical child protection respective child abuse. Here, Christoph Sucherdt sheds light on some reflection on the base of the sociology of knowledge. To this end, from a sociological perspective of knowledge, particular attention is paid to its origins, the development of definitions of ill-treatment, the diagnosis of various forms of violence, and the role of medical research. He shows the consequences if the medicine is dealing with the subject of violence against children, and the consequences of the increasing complexity - for example, hybridization by 
extending the definition of mistreatment - that comes along with medicine dealing with the issue of violence against children.

Similarly, Andreas Kranebitter's micro-sociological view on violent situations shows a certain complexity in acts of violence that cannot be explained by an either-or-logic, exemplified by regarding prisoner functionaries in Nazi concentration camps. Violence in concentration camps was a matter of gradual gradations. Thus, the sociologization of the interpretation of violence in concentration camps could be essential for any theory development and can contribute to the study of concentration camps, including their "grey zones" with their ambivalences and contradictions.

Logically considering such "grey areas" Thomas Kron further develops a central point of Collins' situational approach—the concept of emotional energy — concerning the integration of negative emotional energy. He models emotional energy as a set with gradual memberships and dynamically relates positive and negative emotional energies. Thus, as a new factor in the emergence of violence, the entropy of emotional energy plays a so far neglected key role. In doing so, he shows that various theoretical building blocks of Collins' approach can be formulated more precisely than before.

While many contributions use empirical research to develop theory, Anne Nassauer and Nicolas Legewie focus particularly on the challenge of how to deal with modern data using new methodological and methodical options in empirically "grounded" future research on violence. Hence, in their methodological inventory, they discuss video data analysis, mixed methods, and big data in the context of current and future violence research.

Finally, Mario S. Staller and Swen Körner discuss the importance of taking into account the complexity of violent acts for prevention and specifically for prevention training, e.g., in the police force. They introduce the concept of complex violence prevention and focuses on complexity as an essential part of the practice and training situation. The complexity of violence prevention is mapped on several dimensions and levels, guided by theory, used to reflect on violence prevention. Here, the research results can enrich academic debates on explaining violence by providing information on generative mechanisms including complexity.

We thank all the contributors for their engagement and for getting this special issue done. But, often forgotten is also the important role reviewers play by planning, conceptualizing, and finalizing such projects. All contributions have benefited from thorough comments and criticisms. To all of you, we cannot name here due to the double-blind review process: Thank you very much for supporting us!

\section{Andreas Braun and Thomas Kron}

Funding Open Access funding enabled and organized by Projekt DEAL 
Open Access This article is licensed under a Creative Commons Attribution 4.0 International License, which permits use, sharing, adaptation, distribution and reproduction in any medium or format, as long as you give appropriate credit to the original author(s) and the source, provide a link to the Creative Commons licence, and indicate if changes were made. The images or other third party material in this article are included in the article's Creative Commons licence, unless indicated otherwise in a credit line to the material. If material is not included in the article's Creative Commons licence and your intended use is not permitted by statutory regulation or exceeds the permitted use, you will need to obtain permission directly from the copyright holder. To view a copy of this licence, visit http://creativecommons.org/licenses/by/4. $0 /$.

Andreas Braun, Dr., ist wissenschaftlicher Mitarbeiter in den Arbeitsbereichen Soziologische Theorie (AB 1) und Organisationssoziologie (AB 3) an der Fakultät für Soziologie der Universität Bielefeld. Seine Forschungsschwerpunkte sind Soziologische Theorien (insbesondere Akteurtheorien), Gewaltsoziologie und Neurosoziologie.

Thomas Kron 1992-1997 Studium der Soziologie, Politik- und Medienwissenschaften an der HeinrichHeine-Universität Düsseldorf, 2000 Promotion zum Dr. rer. pol. an der Otto-Friedrich-Universität Bamberg, 2005 Habilitation an der FernUniversität in Hagen. Seit 2007 Univ.-Professor für Soziologie an der RWTH Aachen. Forschungsschwerpunkte sind Soziologische Theorien (insbesondere System- und Akteurtheorien), Fuzzy-Logik in der Soziologie und die Gewaltforschung. 